\title{
Astrocytes Inhibit Schwann Cell Proliferation and Myelination of Dorsal Root Ganglion Neurons in vitro
}

\author{
Veronique Guenard, Lisa A. Gwynn, and Patrick M. Wood \\ The Miami Project to Cure Paralysis and Department of Neurological Surgery, University of Miami School of Medicine, \\ Miami, Florida 33136
}

\begin{abstract}
Schwann cells promote the regrowth of nerve fibers in both the PNS and CNS and might thus be of value in strategies to promote repair following injury or demyelination in the CNS. The effectiveness of Schwann cells in promoting repair could, however, be limited by interactions with reactive astrocytes that are prominent at lesioned and demyelinated sites. To investigate this possibility, experiments were performed to determine the influence of cortical astrocytes on Schwann cell proliferation and myelination of dorsal root ganglion (DRG) neurons in vitro. DRG neurons from embryonic rats and Schwann cells, astrocytes, and fibroblasts isolated from the sciatic nerve, cerebral cortex, and cranial periosteum, respectively, of neonatal rats were purified and then recombined to provide neuron-Schwann cell, neuronSchwann cell-astrocyte, and neuron-Schwann cell-fibroblast cultures. Astrocytes inhibited both neuron-dependent Schwann cell proliferation and the myelination of axons by Schwann cells. The expression of galactocerebroside, but not of the 04 antigen, was inhibited by astrocytes, suggesting that astrocytes blocked Schwann cell differentiation prior to the onset of myelination. Ultrastructural analysis of the cultures also indicated that both axonal ensheathment and the segregation of large axons into 1:1 relationships were decreased in the presence of astrocytes. Astrocytes did not affect the expression of the basal lamina components type IV collagen and laminin, and basal lamina formation assessed by electron microscopy was only slightly decreased. Some of these inhibitory effects appear to be mediated by diffusible factors since astrocyte-conditioned medium also reduced Schwann cell myelination. Fibroblasts or fibroblast-conditioned medium did not induce such inhibitory effects, indicating that the effects were astrocyte specific. We conclude that cortical astrocytes release a soluble
\end{abstract}

\footnotetext{
Received Aug. 5, 1993; revised Oct. 14, 1993; accepted Oct. 26, 1993.

This work was supported by NIH Grant NS 28059 and National Multiple Sclerosis Society Grant RG $2210-A-2$ to P.M.W., and funds from The Miami Project to Cure Paralysis. We are grateful to Dr. John Klose for his help with the statistical analysis; Anna Gomez, Margaret Bates, and Francisco Cruz for excellent technical support; and Robert Camarina for photographic assistance. The laminin, type IV collagen, and $217 \mathrm{c}$ antibodies were generous gifts from Dr. C. Gatchalian (University of Oregon), Dr. A. Charonis (University of Minnesota), and Dr. J. de Vellis (University of California at Los Angeles), respectively. Hybridoma cell lines producing the monoclonal antibodies $\mathrm{O} 4$ and $\mathrm{O} 1$ were a generous gift from $\mathrm{Dr}$. M. Schachner (Zurich, Switzerland).

Correspondence should be addressed to Veronique Guenard, Ph.D., The Miami Project to Cure Paralysis, University of Miami School of Medicine, $1600 \mathrm{NW}$ 10 th Avenue, R-48, Miami, FL 33136.

Copyright (C) 1994 Society for Neuroscience $0270-6474 / 94 / 142980-13 \$ 05.00 / 0$
}

factor(s) that inhibits specific aspects of neuron-Schwann cell interactions leading to myelination.

[Key words: astrocyte, Schwann cell, neuron, proliferation, myelination, differentiation]

Physical injuries to the CNS can cause severe disability and numerous complications in victims of such injuries. The loss of nerve fibers across lesioned sites and of myelin sheaths on surviving fibers contributes to the functional deficits. Recent demonstrations that neurons could regenerate new fibers and that demyelinated fibers could be remyelinated have challenged the older belief that repair of damaged CNS could not occur and inspired a renewed research effort to define conditions and approaches to maximize repair in animal models (David and Aguayo, 1981; Wrathall et al., 1982; Duncan et al., 1988; Paino and Bunge, 1991; Xu et al., 1993). It is well established that Schwann cells, the glial cells of the PNS, enhance peripheral nerve regeneration by creating a supportive terrain for elongating neurites (for review, see Fawcett and Keynes, 1990) and by secreting both neurotrophic and neurotropic factors (e.g., Bandtlow et al., 1987; Muir et al., 1989; Acheson et al., 1991; Rende et al., 1992). Recent studies have demonstrated that Schwann cell-containing implants of PNS tissue support the regeneration of CNS neurons in many different areas of the CNS (Blakemore, 1977; Weinberg and Raine, 1980; David and Aguayo, 1981; Richardson et al., 1982; Wrathall et al., 1982; Kromer and Cornbrooks, 1985; Politis and Spencer, 1986; Smith and Stevenson, 1988; Campbell et al., 1992). Several studies indicate that cultured purified Schwann cells transplanted into damaged or demyelinated areas of the adult mammalian spinal cord support nerve fiber outgrowth and form myelin sheaths (for a review, see Guénard et al., 1993).

Despite these promising findings, the stimulation of regenerative repair by Schwann cells transplanted into the CNS appears to be limited by factors that are poorly understood. A number of observations suggest that reactive astrocytes, often present after injury or demyelination, exert a negative influence on the ability of Schwann cells to function in the CNS (Raine et al., 1978; Harrison, 1980; Sims and Gilmore, 1983; Blakemore et al., 1986; Blakemore and Crang, 1989). Furthermore, both in areas of experimentally demyelinated spinal cord and in multiple sclerosis plaques, myelination of CNS fibers by Schwann cells is observed only in areas containing few astrocytes (Itoyama et al., 1983, 1985). At the PNS-CNS interface in a healthy animal, astrocytes exclude Schwann cells from entering the CNS by an unknown mechanism. After injury astrocytes proliferate rapidly, become hypertrophied, and secrete numer- 
ous humoral factors (Bignami and Dahl, 1976; Nieto-Sampedro et al., 1983; Reier and Houle, 1988; Hatten et al., 1991). Such factors include tumor necrosis factor- $\alpha(\mathrm{TNF}-\alpha)$, prostaglandins, and transforming growth factor- $\beta$ (TGF- $\beta$ ) (Robbins et al., 1987; Cockram, 1990), all of which have been shown to have inhibitory influences on target cells and could act to inhibit the function of transplanted Schwann cells. At the present time, very litle is known from in vivo studies about the nature of interactions that might occur between reactive astrocytes located at a lesion site and transplanted Schwann cells.

Past studies have shown that Schwann cells proliferate in response to a mitogen on neuronal membranes, secrete extracellular matrix (ECM) components, form a complete basal lamina in contact with neurons and ensheathe axons, and produce myelin sheaths only when basal lamina is deposited (Wood and Bunge, 1975; Carey et al., 1983; Bunge et al., 1986, 1989; Eldridge et al., 1989; Kleitman et al., 1991). To determine if astrocytes influence normal interactions between neurons and Schwann cells, we have used new techniques for the isolation and purification of Schwann cells, astrocytes, and neurons and have recombined these cells in vitro. In the present study, we used these culture methods to evaluate the influence of both astrocytes and astrocyte-conditioned medium on neuron-dependent Schwann cell proliferation and on the myclination of dorsal root' ganglion (DRG) axons by Schwann cells. We now report that in our experimental model astrocytes inhibit Schwann cell proliferation and myelination of DRG neurites and slightly decrease basal lamina formation. Myelination was blocked at an early stage in the sequence of events leading to the formation of myelin. Furthermore, our findings suggest that these effects are mediated by a factor(s) released by astrocytes.

\section{Materials and Methods}

\section{Preparation of purified cell populations}

Neuronal cultures. Pure cultures of dissociated rat embryonic dorsal root ganglion (DRG) neurons were obtained according to techniques developed in our laboratory (Bunge et al., 1983; Kleitman et al., 1991). The pure neuronal cultures were subsequently maintained in Eagle's Minimal Essential Medium (EMEM; GIBCO, Long Island, NY) supplemented with $5 \%$ heat-inactivated human placental serum, nerve growth factor (NGF; $50 \mathrm{ng} / \mathrm{ml})$, and glucose $\left(0.4 \%\right.$, w/v) at $35^{\circ} \mathrm{C}$ with $5 \% \mathrm{CO}_{2}$.

Schwann cell cultures. Schwann cells from the sciatic nerve of embryonic day 21 (E21)-postnatal day 1 (P1) Spraguc-Dawlcy rats (Charles River Laboratories, Wilmington, MA) were purified according to the method of Brockes et al. (1979). Schwann cells were allowed to proliferate in Dulbecco's Modified Eagle's Medium containing 10\% heatinactivated fetal bovine serum (FBS) (Hyclone Laboratories, Logan, UT) (D medium) supplemented with pituitary extract $(10 \mu \mathrm{g} / \mathrm{ml}$; Sigma) and forskolin ( $2 \mu \mathrm{M}$; Sigma) (Porter et al., 1986). At least $5 \mathrm{~d}$ prior to the addition of the Schwann cells to the neuronal cultures, the mitogens were removed from the medium in which the Schwann cells were maintained. This ensured that Schwann cell proliferation observed in the neuron-Schwann cell cocultures was due to axonal contact rather than to residual soluble exogenous mitogens. Schwann cells were grown in a humidified atmosphere at $37^{\circ} \mathrm{C}$ with $5 \% \mathrm{CO}_{2}$. The purity of the cultures was determined by immunostaining for S-100, a Schwann cell marker, Thy-1.1, a fibroblast marker (Raff ct al., 1979), and OX-42, a macrophage marker (Robinson et al., 1986). After labeling, the cultures were mounted on glass slides in Citifluor mountant (University College, London, UK) containing the fluorescent nuclear dye Hoechst $33342(5 \mu \mathrm{M}$; Sigma). The monoclonal OX-42 antibody was purchased from Bioproducts for Science (Indianapolis, IN) and the hybridoma cell line making the Thy-1.1 antibody was purchased from American Tissue Culture Collection (ATCC). The percentages of S-100-, Thy-1.1-, and OX-42-positive cells were evaluated using a Zeiss Universal microscope adapted for epifluorescence at a final magnification of $400 \times$. For each immunostain, an average of 500 cells was counted. The cultures were approximately $98.7 \%$ pure Schwann cells (S-100-positive cells); $1.3 \%$ of the cells were fibroblasts (Thy-1.1-positive cells), and no macrophages were observed.

Astrocyte cultures. Astrocytes were obtained from the cortex of E21P1 Sprague-Dawley rats using a modification of the method of McCarthy and de Vellis (1980). The cortical cell suspension was fractionated on an $80 \%$ Percoll gradient in $0.25 \mathrm{M}$ sucrose with $0.02 \mathrm{M}$ phosphate buffer at $30,000 \times g$ for $45 \mathrm{~min}$ at $4^{\circ} \mathrm{C}$ to remove the cellular debris and red blood cells (Rosen et al., 1989). The cell layer found above the red blood cell layer was then collected, filtered through a $15 \mu \mathrm{m}$ Nitex filter (Tetko Inc., Briar Crest, NY), and plated into $25 \mathrm{~cm}^{2}$ Falcon flasks in D medium. The cells were allowed to proliferate for 8-10 d, and then the cultures were shaken overnight at $150 \mathrm{rpm}$ to remove contaminating oligodendrocytes that were located on top of the astrocyte monolayer (McCarthy and de Vellis, 1980). The cultures were then treated once with fluorodeoxyuridine ( $2 \mu \mathbf{M}$; Sigma) to eliminate remaining rapidly proliferating meningeal, epithelial, and microglial cells. The purified astrocytes were then replated onto $100 \mathrm{~mm}$ Petri dishes, allowed to proliferate in D medium, and subcultured no more than four times (approximately 1 month in vitro). The time astrocytes were maintained in culture was kept short to minimize the possibility that the properties of the astrocytes would change with time in vitro. The astrocyte cultures were maintained at $37^{\circ} \mathrm{C}$ in $5 \% \mathrm{CO}_{2}$. The composition of the cultures was evaluated by immunostaining for glial fibrillary acidic protein (GFAP), an astrocyte marker (Bignami et al., 1972); O4, a marker for both oligodendrocyte precursors and oligodendrocytes (Bansal et al., 1989); O1, an oligodendrocyte-specific monoclonal antibody that recognizes galactocerebroside (Sommer and Schachner, 1981; Bansal et al., 1989); A2B5, a marker for oligodendrocyte progenitors and for type 2 astrocytes (Raff et al., 1983); Thy 1.1; and OX-42. Polyclonal GFAP antibody was purchased from Biomedical Technologies Inc. (Stoughton, MA) and the hybridoma cell line making A2B5 antibody was purchased from ATCC. The composition of the cultures was determined by counting as described above. The cultures were $98.5 \%$ pure astrocytes (GFAPpositive cells). Of these, $97.1 \%$ were type 1 astrocytes (A2B5-negative cells) and $1.4 \%$ were type 2 astrocytes (A2B5-positive cells). The cultures also contained $1.3 \%$ undifferentiated and differentiated oligodendrocytes (O4- and $\mathrm{O} 1$-positive cells), $0.05 \%$ fibroblasts, and $0.1 \%$ macrophages.

Fibroblast cultures. To determine whether the effects observed with astrocytes could be due to cellular overloading or to the trauma of adding cells to the cultures, fibroblasts that expand in culture in a similar way to astrocytes were added to some neuron-Schwann cell (N-SC) cultures in parallel with astrocytes. Fibroblasts were obtained from the cranial periosteum of E15 Sprague-Dawley rats as reported by Rosen et al. (1989). Fibroblasts were subcultured no more than three times (approximately 1 month in vitro) and maintained in EMEM supplemented with $0.4 \%$ glucose, NGF $(50 \mathrm{ng} / \mathrm{ml})$, and $10 \%$ FBS $(C$ medium $)$ in a humidified atmosphere of $5 \% \mathrm{CO}_{2}$ at $35^{\circ} \mathrm{C}$. The composition of the cultures was evaluated by immunostaining with the anti-Thy 1.1 and anti-OX-42 antibodies. Cultures were $99.6 \%$ fibroblasts and $0.4 \%$ macrophages.

Preparation of astrocyte- and fibroblast-conditioned media. $\mathrm{O}$ medium [consisting of EMEM supplemented with $0.4 \%$ glucose, NGF $(50 \mathrm{ng}$ / $\mathrm{ml}), 1 \% \mathrm{FBS}$, insulin $(50 \mu \mathrm{g} / \mathrm{ml}$; Sigma), putrescine (100 $\mu \mathrm{M}$; Sigma), progesterone (20 pM; Sigma), sodium selenite (30 pM; Pflatz \& Bauer, Waterbury, CT), and transferrin $(10 \mu \mathrm{g} / \mathrm{ml}$; Jackson Immunoresearch Labs, West Grove, PA)] was conditioned by confluent astrocyte or fibroblast monolayers for a $3 \mathrm{~d}$ period at $37^{\circ} \mathrm{C}$ with $5 \% \mathrm{CO}_{2}(\mathrm{O}-\mathrm{ACM}$ and $\mathrm{O}-\mathrm{FbCM}$ media, respectively) and filtered through a $0.22 \mu \mathrm{m}$ Millipore filter. The conditioned media were aliquoted and stored at $-80^{\circ} \mathrm{C}$. Myelinating $M$ medium consisting of FMFM supplemented with $0.4 \%$ glucose, NGF $(50 \mathrm{ng} / \mathrm{ml}), 15 \%$ FBS, and L-ascorbic acid $(50 \mu \mathrm{g} / \mathrm{ml}$; Sigma) was conditioned overnight by astrocytes, filtered, pooled, and used fresh (M-ACM). Prior to use, all conditioned media were diluted $1: 1(\mathrm{v} / \mathrm{v})$ with fresh medium.

Preparation of the combined cultures. Schwann cells and astrocytes were detached from plates by trypsinization, rinsed, and counted using a hemocytometer. Fibroblasts were collected after gently scraping the dishes, washed, and counted. Prior to seeding, neuronal cultures were rinsed with medium appropriate for either a proliferation or myelination assay (see below) and 50,000 Schwann cells suspended in similar medium were added to produce neuron-Schwann cell (N-SC) cultures. Astrocytes or fibroblasts were added either with the Schwann cells or later as described below to produce neuron-Schwann cell-astrocyte (N- 
SC-A) or neuron-Schwann cell-fibroblast (N-SC-Fb) cultures. To test the effects of factors released by astrocytes, some N-SC cultures were fed with medium containing 50\% astrocyte-conditioned medium (NSC-ACM cultures). N-SC cultures treated with fibroblast-conditioned medium (N-SC-FbCM cultures) were used as controls.

\section{Method to determine the effect of astrocytes on Schwann cell proliferation}

$\mathrm{N}$-SC cultures established in $\mathrm{O}$ medium received either 150,000 or 500,000 astrocytes or fibroblasts at the same time as the addition of Schwann cells or were maintained in medium containing astrocyte- or fibroblast-conditioned medium. Twenty-four hours after the start of the coculture period, N-SC, N-SC-A, N-SC-Fb, N-SC-ACM, and N-SCFbCM cultures were pulsed for $2 ? \mathrm{hr}$ with ${ }^{3} \mathrm{H}$-thymidine $(0.5 \mu \mathrm{Ci} / \mathrm{ml}$; New England Nuclear, Boston, MA) in O medium and then immunostained and processed for autoradiography. Schwann cells and astrocytes, respectivcly, were labeled using anti-217c antibody, which recognizes the NGF receptor (Kumar et al., 1990), and anti-GFAP antibody. Cultures were rinsed, blocked with $\mathrm{L}-15$ containing $10 \%$ normal goat serum, and incubated for $30 \mathrm{~min}$ each at $4^{\circ} \mathrm{C}$ with anti-217c antibody $(1: 100)$ followed by rhodamine-conjugated goat anti-mouse secondary antibody (1:100; Cappel/Organon Teknika, West Chester, PA). The cultures were then fixed for $10 \mathrm{~min}$ using $4 \%$ paraformaldehyde in $0.1 \mathrm{M}$ phosphate buffer and permeabilized with $0.2 \%$ Triton X-100 in fixative and with acetone. The cultures were then incubated with anti-GFAP antibody $(1: 100)$ and fluorescein-conjugated goat anti-rabbit antibody (1:50; Cappel/Organon Teknika) for 30 min each at $4^{\circ} \mathrm{C}$. After rinsing with buffer and distilled water, the coverslips were dipped into $100 \%$ ethanol, air dried, and mounted face up onto glass slides. The cultures were then dipped into NTB-2 Kodak emulsion and kept in a light-tight box for at lcast $5 \mathrm{~d}$ at $4^{\circ} \mathrm{C}$. The autoradiograms were developed, fixed, rinsed, air dried, and coverslipped using Citifluor/Hoechst 33342 dye mountant. For each condition in each experiment, cultures with comparable cellular organization and density were analyzed. A minimum of 500 $217 \mathrm{c}$-positive cells associated with DRG neurites were evaluated on randomly selected fields from each culture at a final magnification of $400 \times$. Among these cells, the number of ${ }^{3} \mathrm{H}$-thymidine-positive cells was counted. All cells containing at least 10 silver grains over their nucleus were considered ${ }^{3} \mathrm{H}$-thymidine positive. The Schwann cell labeling index, expressed as a percentage, was defined as the ratio of the number of ${ }^{3} \mathrm{H}$-thymidine-positive and $217 \mathrm{c}$-positive cells over the total number of $217 \mathrm{c}$-positive cells, times 100 .

\section{Methods to determine the effect of astrocytes on Schwann cell differentiation/myelination}

Effect of astrocytes on Schwann cell differentiation. To study the effect of astrocytes on Schwann cell differentiation, N-SC, N-SC-A, and N-SCACM cultures were prepared in M medium. N-SC-A cultures received 100,000 astrocytes together with the Schwann cells and N-SC-ACM cultures were fed with a 1:1 mixture of M:O-ACM medium supplemented with FBS, crude NGF, and L-ascorbic acid to final concentrations of $M$ medium. The experiment was performed three times. At 6 and $8 \mathrm{~d}$ after starting myelination, two or three cultures from each condition were immunostained with the differentiation stage-specific antibodies $\mathrm{O} 4$ and $\mathrm{Ol}$ (Bansal et al., 1989). The O4 antigen is an uncharacterized molecule that begins to be expressed on the surface of neuron-associated Schwann cells prior to myelination, whereas the $\mathrm{O} 1$ antigen is galactocerebroside, expressed at the onset of myelination. Thus, O4-positive/O1-positive Schwann cells are more differentiated than O4-positive/O1-negative Schwann cells. The cultures were immunostained using anti-Ol antibody (supernatant; Sommer and Schachner, 1981) and rhodamine-conjugated goat anti-mouse antibody (1:50) followed by anti-O4 antibody (supernatant) and fluorescein-conjugated goat anti-mouse antibody (1:50; Cappel/Organon Teknika), fixed, and mounted on glass slides as described above. The cultures were examined for the presence of O4-and O1-positive Schwann cells. Since O4 was expressed on nearly all Schwann cells in all conditions, the number of O4-positive cells was not counted. The number of O1-positive cells per culture at day 8 was evaluated in three cultures per condition using an eyepiece grid. The numbers of $\mathrm{O} 1$-positive cells were averaged, giving the number of Ol-positive cells per field.

Effect of astrocytes on Schwann cell myelination. To determine the long-term effects of astrocytes on Schwann cell myelination, different types of cells were recombined with purified neuronal cultures as de- scribed above, except that Schwann cells were allowed to proliferate on the neurites for 2 weeks prior to adding 100,000 astrocytes or astrocyteconditioned medium (M-ACM or resupplemented O-ACM) and initiating myelination. Prior to the addition of astrocytes or initiating trcatment with astrocyte-conditioned medium, the cultures were maintained in $C$ medium. Myelination was initiated by switching $C$ medium with $M$ medium.

Sudan black staining was performed as reported by Wood and Williams (1984) in cultures maintained in M medium for 2 and 4 weeks, taken from three experiments. Myelination in two cultures per condition per experiment was assessed using an Olympus light microscope at a final magnification of $200 \times$. The center of the cultures was determined and fields were counted every $2 \mathrm{~mm}$ along three lines located $1 \mathrm{~mm}$ above, $1 \mathrm{~mm}$ below, and at the level of the center of the culture. The amount of myelin in each field was quantified using an eyepiece grid divided into 100 squares, with lines $700 \mu \mathrm{m}$ apart. Each of these squares was scored 0-5 depending on whether a portion of a number of myelin segments crossed the square. An average of 30 ficlds per culturc sclceted by stage coordinates was evaluated. The scores were added and averaged over the total number of fields counted per culture, giving an estimate of the average amount of myelin per field.

Immunostaining for extracellular matrix components. To assess whether astrocytes or ACM influenced myelination by affecting the expression of some basal lamina components, 2 weeks postfeeding with $\mathrm{M}$ medium, some of the cultures were immunostained with antibodies against laminin and type IV collagen. Living cultures were incubated with either anti-laminin (1:100) or anti-collagen type IV (1:100) antibodies followed by fluorescein goat anti-rabbit antibody $(1: 50)$, and then fixed and mounted on glass slides as reported above.

Electron microscopy. Control and astrocyte-seeded cultures myelinated for 2 weeks were processed and embedded in Polybed (Polysciences Inc., Warrington, PA) as described previously (Bunge et al., 1989). Arcas containing large neurite fascicles and Schwann cells were visualized by phase-contrast microscopy, scored, excised, and mounted onto blank plastic blocks. Ultrathin sections were obtained using a Reichart-Jung microtome and stained with Reynold's lead citrate and uranyl acetate. Seven areas from three control cultures and six areas from three experimental cultures taken from three different experiments were examined for the extent of basal lamina formation, and for the extent to which Schwann cells had ensheathed axons and formed 1:1 relationships using a Philips CT-10 transmission electron microscope. An axon was considered ensheathed if at least $50 \%$ of its surface was in apposition with Schwann cell cytoplasm. An axon was determined to be in a 1:1 relationship with a Schwann cell when the axon was completely isolated and surrounded by a single Schwann cell. Both myelinated and nonmyelinated axons engaged in a $1: 1$ relationship werc counted. The percentage of ensheathed axons and 1:1 relationships were determined for each analyzed culture.

\section{Neuronal morphology assay}

To determine the influence of astrocytes or ACM on neuronal health and viability, the effect of astrocytes and ACM on the size and morphology (eccentric or pycnotic nuclei, presence of chromatolytic response) of the neuronal cell bodies was assessed. Neuronal cultures were either seeded with 100,000 astrocytes (N-A cultures) and maintained in M medium or fed with M:M-ACM (1:1) medium (N-ACM cultures) Neuronal cultures maintained in $\mathrm{M}$ medium were used as controls. The media were changed every $2 \mathrm{~d}$ for 4 weeks. Neuronal morphology was assessed by toluidine blue staining. The cultures were fixed, rinsed in $0.1 \mathrm{M}$ PBS at pH 7.4, soaked for $30 \mathrm{sec}$ in stain consisting of $1 \%$ each of methylene blue, toluidine blue, and borax in water, rinsed in buffer, dehydrated in ethanol, dipped in xylenc, and mounted in DPX on glass slides. The morphology of the neurons was examined and the size of the neuronal soma of 80-100 neurons per culture determined using an Olympus light microscope at a final magnification of $400 \times$; two cultures per condition were evaluated.

\section{Preliminary characterization of the astrocyte factor(s)}

Preliminary experiments to determine the heat stability of the factor(s) were performed. Astrocyte-conditioned medium was heated at either $56^{\circ} \mathrm{C}$ or $100^{\circ} \mathrm{C}$ for 30 min prior to testing. Activity of the astrocyte factor(s) in the heated conditioned media was then evaluated using the proliferation assay.

In view of the evidence that astrocytes secrete factors with transform- 
Table 1. Inhibition of Schwann cell proliferation by astrocytes and astrocyte-conditioned medium

\begin{tabular}{llllll} 
& \multicolumn{2}{l}{$\begin{array}{l}150,000 \text { astrocytes per } \\
\text { culture }\end{array}$} & & \multicolumn{2}{l}{$\begin{array}{l}500,000 \text { astrocytes per } \\
\text { culture }\end{array}$} \\
\cline { 2 - 3 } \cline { 5 - 6 } Condition & $\begin{array}{l}\text { Schwann cell } \\
\text { L.I. }(\%)\end{array}$ & $\begin{array}{l}\text { Inhibition } \\
(\%)\end{array}$ & $\begin{array}{l}\text { Schwann cell } \\
\text { L.I. }(\%)\end{array}$ & $\begin{array}{l}\text { Inhibition } \\
(\%)\end{array}$ \\
\hline Control & $73.6 \pm 18.4$ & & $63.0 \pm 5.2$ & \\
Astrocytes & $48.0 \pm 21.2$ & 34.7 & & $16.8 \pm 5.4^{*}$ & 74.6 \\
Fibroblasts & $69.7 \pm 19.8$ & 5.3 & & $56.3 \pm 4.8$ & 10.0 \\
O-ACM & NA & NA & & $51.4 \pm 7.9$ & 19.2 \\
O-FbCM & NA & NA & $68.2 \pm 4.4$ & 0
\end{tabular}

Proliferating Schwann cells were counted on whole-mounted cultures processed for autoradiography (see Materials and Methods). The Schwann cell labeling index (L.I.) was defined as the ratio of ${ }^{3} \mathrm{H}$-thymidine-positive Schwann cells over the total number of 217c-positive Schwann cells. Values shown are means \pm SEM of determinations on cultures from two (150,000 astrocytes) and seven (500,000 astrocytes) experiments, respectively. One-way ANOVA followed by Tukey posttest comparisons was used to test significance between pairs of means.

* Statistical significance $(p<0.05)$ between control and any other condition.

ing growth factor- $\beta$ (TGF- $\beta$ ) activity (Constam et al., 1992), and that TGF- $\beta$ is known to have effects on cellular proliferation and differentiation (for review, see Barnard et al., 1990), fresh O-ACM was also tested for TGF- $\beta$-like activity. Conditioned medium was heated at $80^{\circ} \mathrm{C}$ for 8 min to activate latent TGF- $\beta$ that could be present in the medium. The conditioned medium was first assayed for TGF- $\beta$-induced inhibition of proliferation of CCL-64 mink lung epithelial (Mv1 Lu) cells (Danielpour et al., 1989) with or without heating. The heated conditioned medium was then tested in N-SC cultures; a blocking experiment was also performed by adding a monoclonal antibody to TGF- $\beta 1$ (10 $\mu \mathrm{g} / \mathrm{ml}$; R \& D Systems, Minneapolis, MN) to heated conditioned medium. It has been reported that astrocytes can be stimulated by lipopolysaccharide to secrete a factor with tumor necrosis factor- $\alpha$ (TNF$\alpha$ ) activity (Robbins et al., 1987; Lieberman et al., 1989) that has been shown to have detrimental effects on oligodendrocytes (Robbins et al., 1987; Selmaj et al., 1991). An assay for TNF- $\alpha$ activity in astrocyteconditioned medium was established using WEHI 164 cells, which are killed by picomolar amounts of TNF- $\alpha$ (Vanderslice and Collins, 1991). For this assay, WEHI 164 cells growing in Optimum medium (GIBCO) supplemented with 10\% FBS were resuspended and plated onto collagen-coated Aclar coverslips at 25,000 cells per coverslip. Twenty-four hours later, the WEHI 164 cells were treated with ACM diluted 1:1 with Optimum:FBS medium. After $24 \mathrm{hr}$, the WEHI 164 cells were stained with trypan blue and the number of viable cells determined. WEHI 164 cells were purchased from ATCC.

\section{Statistical analysis}

Data are presented as mean \pm SEM. One-way analysis of variance (between conditions) followed by Tukey HSD posttest comparisons between mean individual cells was used. Statistical analysis was performed using a commercially available software program (StatSoft Inc., Tulsa, OK). Statistical significance was accepted for $p<0.05$.

\section{Results}

The cultures used in this study consisted of dissociated purified sensory DRG neurons to which purified Schwann cells were added. The neuronal somata were scattered within an area in the center of the cultures, with their bare neurites growing radially toward the periphery. Whether Schwann cells were added to the cultures alone or together with astrocytes or fibroblasts, Schwann cells were always aligned along the neurites (Fig. 1 $A$ ), whereas astrocytes and fibroblasts formed a flat monolayer on the entire surface of the coverslips. By electron microscopy, it was possible to observe that astrocytes and fibroblasts had formed a monolayer underneath the neurons.
Table 2. Inhibition of myelination by astrocytes and $\mathrm{M}-\mathrm{ACM}$

\begin{tabular}{|c|c|c|c|c|}
\hline \multirow[b]{2}{*}{ Condition } & \multicolumn{2}{|l|}{2 weeks } & \multicolumn{2}{|l|}{4 weeks } \\
\hline & $\begin{array}{l}\text { Amount } \\
\text { of myelin } \\
\text { per field }\end{array}$ & $\begin{array}{l}\text { Inhibi- } \\
\text { tion } \\
(\%)\end{array}$ & $\begin{array}{l}\text { Amount } \\
\text { of myelin } \\
\text { per field }\end{array}$ & $\begin{array}{l}\text { Inhibi- } \\
\text { tion } \\
(\%)\end{array}$ \\
\hline Control & $179 \pm 17$ & & $174 \pm 35$ & \\
\hline Astrucyles & $40 \pm 29^{*}$ & 77.6 & $58 \pm 38^{*}$ & 67.0 \\
\hline M-ACM & $136 \pm 2$ & 24.0 & $123 \pm 13$ & 29.3 \\
\hline
\end{tabular}

Myelin segments were counted on Sudan black-stained whole-mounted cultures 2 and 4 weeks after switching to $M$ medium (see Materials and Methods). M-ACM was used, diluted $1: 1(\mathrm{v} / \mathrm{v})$ with fresh $M$ medium. Values shown are means and SEM of deten minations on duplicate or triplicate cultures in each group. One-way ANOVA followed by Tukey posttest comparisons was used to test significance between pairs of means.

* Statistical significance $(p<0.05)$ between control and astrocyte or ACM groups.

\section{Astrocytes block Schwann cell proliferation}

To determine the effects of astrocytes on neuron-induced Schwann cell proliferation (Salzer et al., 1980), Schwann cells were added to the neuronal cultures alone or together with astrocytes or fibroblasts. The proliferation assay was performed in defined medium. Analysis of cultures obtained from seven experiments indicated that more Schwann cells were labeled with tritiated thymidine in N-SC cultures than in N-SC-A cultures (Fig. $1 A-C, G-I$ ); the difference was statistically significant. Astrocytes inhibited Schwann cell proliferation in a dose-dependent manner (Table 1 , Fig. $1 A, B, D, E$ ). For similar seeding densities $(500,000$ cells per culture), astrocytes inhibited prolifcration by $74.6 \%$ whercas fibroblasts decrcascd Schwann cell proliferation by $10 \%$. Astrocytes seeded at a lower density ( 150,000 cells per culture) inhibited proliferation by $34.7 \%$. The fact that fibroblasts only slightly affected the Schwann cell labeling index indicates that the effect on Schwann cell proliferation was a specific property of the astrocytes. A lower Schwann cell labeling index was also consistently observed in N-SC-ACM cultures than in N-SC cultures (Table 1, Fig. 1B,C,E,F). An effect of the astrocyte-conditioned medium could not, however, be definitively demonstrated (Table 1). Schwann cell proliferation was not affected by fibroblast-conditioned medium (Table 1).

\section{Astrocytes and astrocyte-conditioned medium block Schwann cell myelination}

Myelination was evaluated on Sudan black-stained cultures. Thin myclin scgments were scattered over the cultures; the Schwann cell nucleus was located at the midpoint of these segments, protruding from the myelin sheath. Myelination in N-SC cultures was compared to that in N-SC-A and N-SC-ACM cultures 2 weeks after switching to $\mathrm{M}$ medium. Quantitative analysis indicated a $73.5 \%$ average decrease $(69.4 \%, 77.6 \%)$ in the formation of myelin in astrocyte-containing cultures when compared to control cultures (Tables 2, 3; Fig. $2 A, B$ ); the inhibition of myelination induced by astrocytes was statistically significant when compared to control cultures. This inhibition appears to be partially mediated by a diffusible factor(s) released by the astrocytes since myelination was also decreased in cultures exposed to astrocyte-conditioned medium (Tables 2, 3; Fig. 2C). When serum-containing medium was used (Table 2) the decrease in myelination was not statistically significant, whereas when the experiment was performed using low serum-contain- 

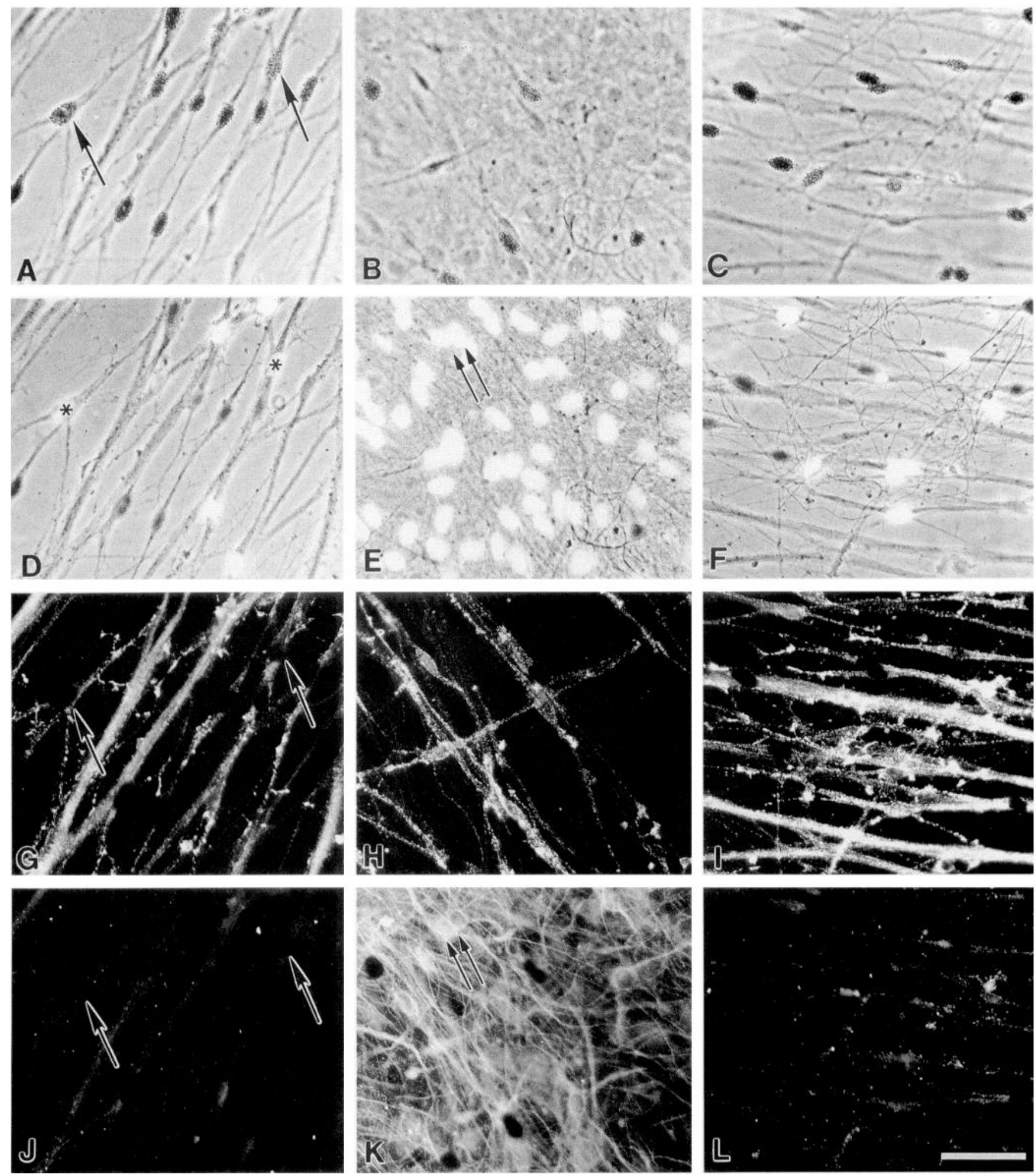

Figure 1. Schwann cell proliferation in N-SC $(A, D, G, J)$, N-SC-A $(B, E, H, K)$, and N-SC-ACM $(C, F, I, L)$ cultures. Phase-contrast $(A, D)$ and fluorescence micrographs show immunostaining for $217 \mathrm{c}(G)$ and GFAP $(J)$ in an N-SC culture processed for autoradiography. Schwann cells are lying along axons $(A)$ with the position of their nucleus marked with the Hoechst nuclear dye $(D$, asterisks). Schwann cells $(G$, arrows $), 217 \mathrm{c}$ positive, are GFAP negative $\left(J\right.$, arrows) and show silver grains above their nuclei when dividing $\left(A\right.$, arrows; ${ }^{3} \mathrm{H}$-thymidine positive). In cultures containing astrocytes, astrocytes occupy a flat monolayer that is indistinct by phase microscopy $(B, E)$; astrocytes are recognizable by their large Hoechststained nuclei $(E$, double arrow) and by light immunostaining for GFAP $(K$, double arrow). The morphological appearance of N-SC-ACM cultures under phase-contrast microscopy $(C, F)$ resembles that in N-SC cultures $(A, D)$. Note the decrease in the number of ${ }^{3} \mathrm{H}$-thymidine-positive cells in N-SC-A $(B)$ cultures as compared to N-SC $(A)$ cultures. Scale bar, $50 \mu \mathrm{m}$. 
Table 3. Inhibition of myelination by astrocytes and O-ACM

\begin{tabular}{lcl} 
Condition & $\begin{array}{l}\text { Amount of myelin } \\
\text { per culture }\end{array}$ & $\begin{array}{l}\text { Inhibition } \\
(\%)\end{array}$ \\
\hline Control & $203 \pm 22$ & \\
Astrocytes & $62 \pm 36^{*}$ & 69.4 \\
O-ACM & $54 \pm 10^{*}$ & 73.4
\end{tabular}

Myelin segments were counted on Sudan black-stained whole-mounted cultures 2 weeks after switching to $\mathrm{M}$ medium (see Materials and Methods). O-ACM supplemented with FBS, NGF, and L-ascorbic acid to the final concentrations of $\mathrm{M}$ medium was used, diluted 1:1 ( $\mathrm{v} / \mathrm{v})$ with fresh $\mathrm{M}$ medium. Values shown are means and SEM of determinations on duplicate or triplicate cultures in each group. One-way ANOVA followed by Tukey posttest comparisons was used to test significance between pairs of means.

* Statistical significance $(p<0.05)$ between control and astrocyte or ACM groups.

ing astrocyte-conditioned medium, the inhibitory effect of the astrocyte factor(s) increased significantly (Table 3).

An assessment of myelination in cultures maintained for 4 weeks indicated that the inhibition of myelination induced by astrocytes was slightly reduced as compared to 2 weeks (Table 2 ); this decrease in inhibition with time was not, however, statistically significant. Furthermore, maintaining the cultures for 4 weeks did not reduce the inhibition of myelination produced by the factor(s) present in astrocyte-conditioned medium (Table 2). Thus, the inhibitory influence of astrocytes and their conditioned medium did not decrease with time. Segments of degrading myelin were very rarely seen. In a single experiment, we determined if astrocytes and astrocyte-conditioned medium would induce myelin degradation in already myelinated N-SC cultures. Two weeks after adding astrocytes or starting astrocyteconditioned medium treatment, the amount of degrading myelin, seen as short rows of Sudan black-stained droplets, was comparable in N-SC-A, N-SC-ACM, and N-SC cultures (data not shown). Thus, we conclude that astrocytes or astrocyteproduced factors do not cause myelin breakdown.

\section{Astrocytes inhibit $O 1$ expression}

To evaluate at what stage of Schwann cell differentiation astrocytes exerted their effects, N-SC, N-SC-A, and N-SC-ACM cultures were immunostained for the differentiation molecules $\mathrm{O} 4$ and $\mathrm{O} 16$ and $8 \mathrm{~d}$ after switching to $\mathrm{M}$ medium. Within $6 \mathrm{~d}$ Schwann cells expressed $\mathrm{O} 4$ in all culture groups, whereas O1positive Schwann cells were observed only in the control N-SC cultures, mostly in the outer part of the cultures (data not shown). After $8 \mathrm{~d}$, the intensity of the $\mathrm{O} 4$ staining had increased and was similar in all cultures although the labeling was slightly patchy in the presence of astrocytes (Fig. $3 A, C, E$ ). The number of O1-positive Schwann cells increased in the control cultures (Fig. $3 B$ ), whereas relatively fewer O1-positive Schwann cells were present in the N-SC-A (Fig. 3D) and N-SC-ACM (Fig. 3F) cultures. N-SC-A cultures showed the fewest O1-positive Schwann cells. Quantitative analysis at day 8 (data not shown) indicated that astrocytes and astrocyte-conditioned medium inhibited the expression of $\mathrm{O} 1$ by $99.1 \%$ and $62.7 \%$, respectively. The length of the myelin segments was also shorter in N-SC-A than in N-SC cultures (Fig. $3 B, D$ ). Astrocytes thus appear to inhibit the expression of the $\mathrm{Ol}$ antigen in Schwann cells; this suggests that astrocytes interfere with the differentiation of the Schwann cells at a step prior to the onset of myelination.
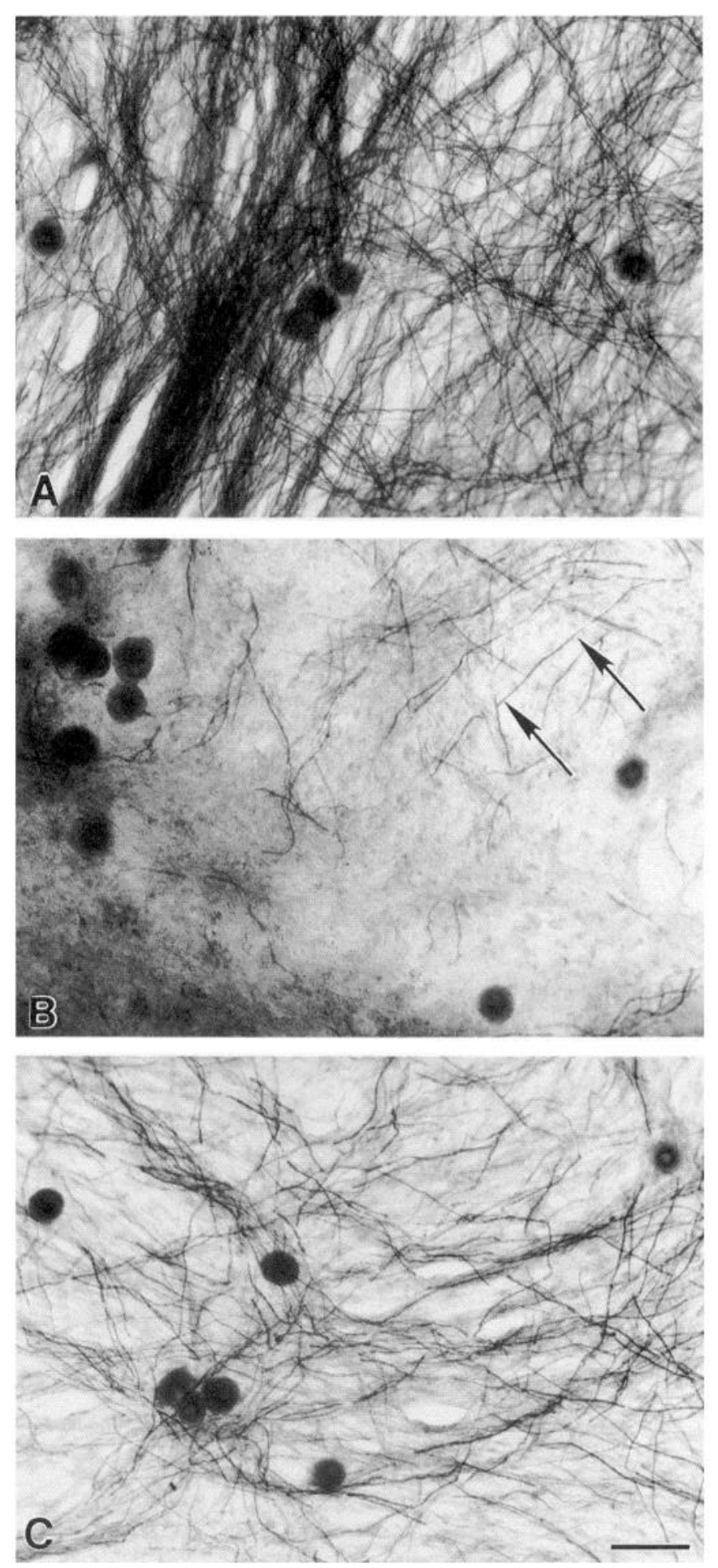

Figure 2. Myelination in N-SC $(A)$, N-SC-A $(B)$, and N-SC-ACM $(C)$ cultures: Sudan black-stained areas of myelination in cultures of comparable organization and density grown in myelinating medium for 2 weeks. Long, thin myelin segments are stained in black (arrows). Note the difference in the number of myelin segments in control cultures $(A)$ versus cultures containing astrocytes $(B)$ or maintained in medium containing $\mathrm{ACM}(C)$. The number of myelin sheaths is strikingly reduced in cultures containing astrocytes. Scale bar, $100 \mu \mathrm{m}$. 

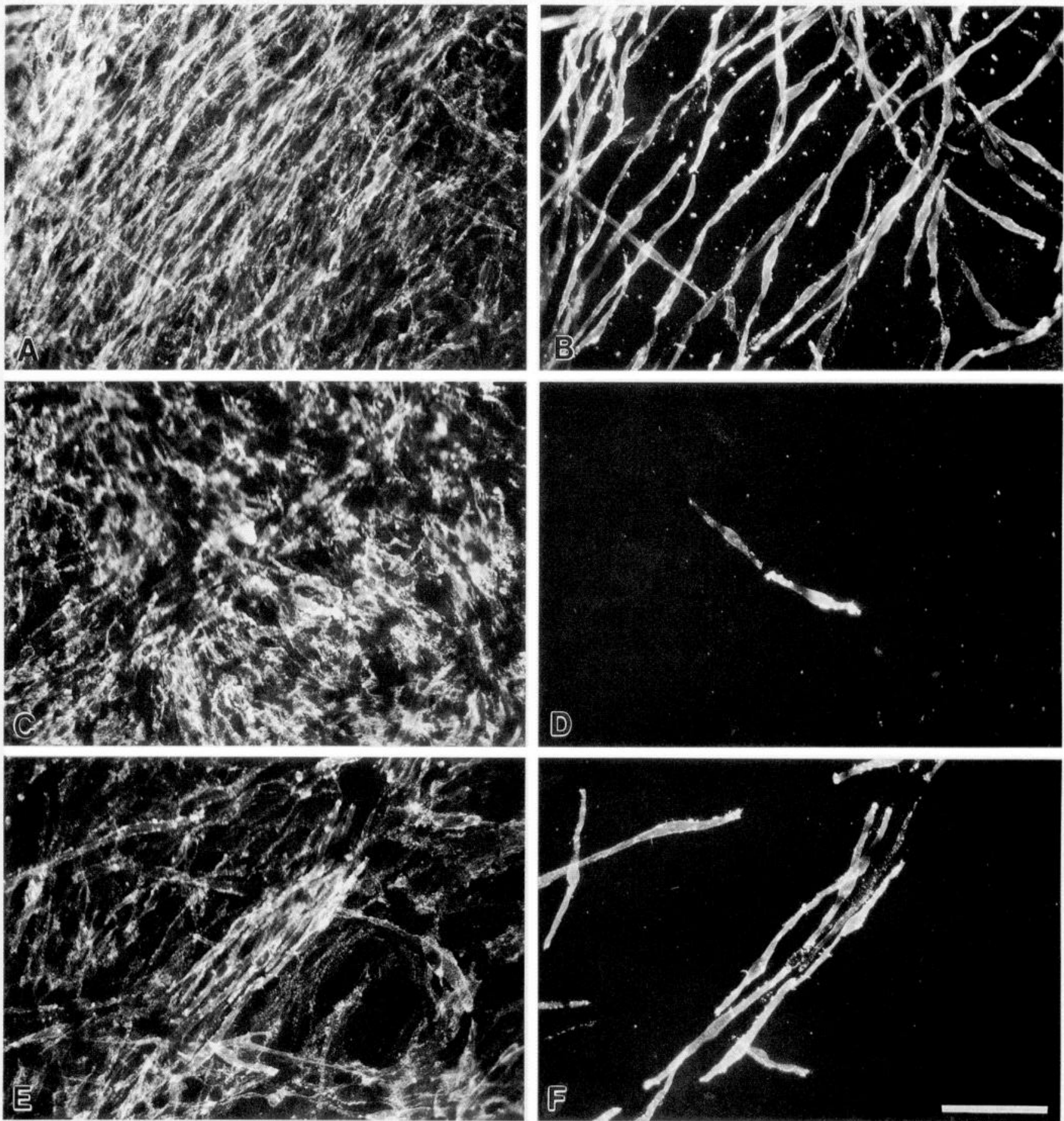

Figure 3. Expression of the $\mathrm{O} 4$ and $\mathrm{Ol}$ antigens in $\mathrm{N}-\mathrm{SC}, \mathrm{N}-\mathrm{SC}-\mathrm{A}$, and $\mathrm{N}-\mathrm{SC}-\mathrm{ACM}$ cultures $8 \mathrm{~d}$ after switching to myelinating medium: fluorescence micrographs of N-SC $(A, B)$, N-SC-A $(C, D)$, and N-SC-ACM $(E, F)$ cultures immunostained for O4 $(A, C, E)$ and $\mathrm{O} 1(B, D, F)$. In all types of cultures, Schwann cells are $\mathrm{O} 4$ positive $(A, C, E)$, although the staining is slightly patchy in the presence of astrocytes $(C)$. Note the apparent decrease in the length of O1-positive Schwann cells in cultures containing astrocytes and the decrease in the number of O1-positive Schwann cells in N-SC-A and N-SC-ACM cultures. Scale bar, $100 \mu \mathrm{m}$.

Astrocytes and astrocyte-conditioned medium do not affect the expression of laminin and type IV collagen

The possibility that astrocytes affected myelination by influencing the deposition by Schwann cells of the basal lamina molecules collagen type IV and laminin was evaluated in N-SC,
N-SC-A, and N-SC-ACM cultures 2 weeks after switching to M medium. There was no difference between culture groups in the intensity and pattern of immunostaining for collagen type IV or laminin. Both nonmyelinating and myelinating Schwann cells (Fig. $4 A, B, E, F)$ displayed type IV collagen and laminin on their surface in the presence of astrocytes (Fig. $4 C, D, G, H$ ). Data are 

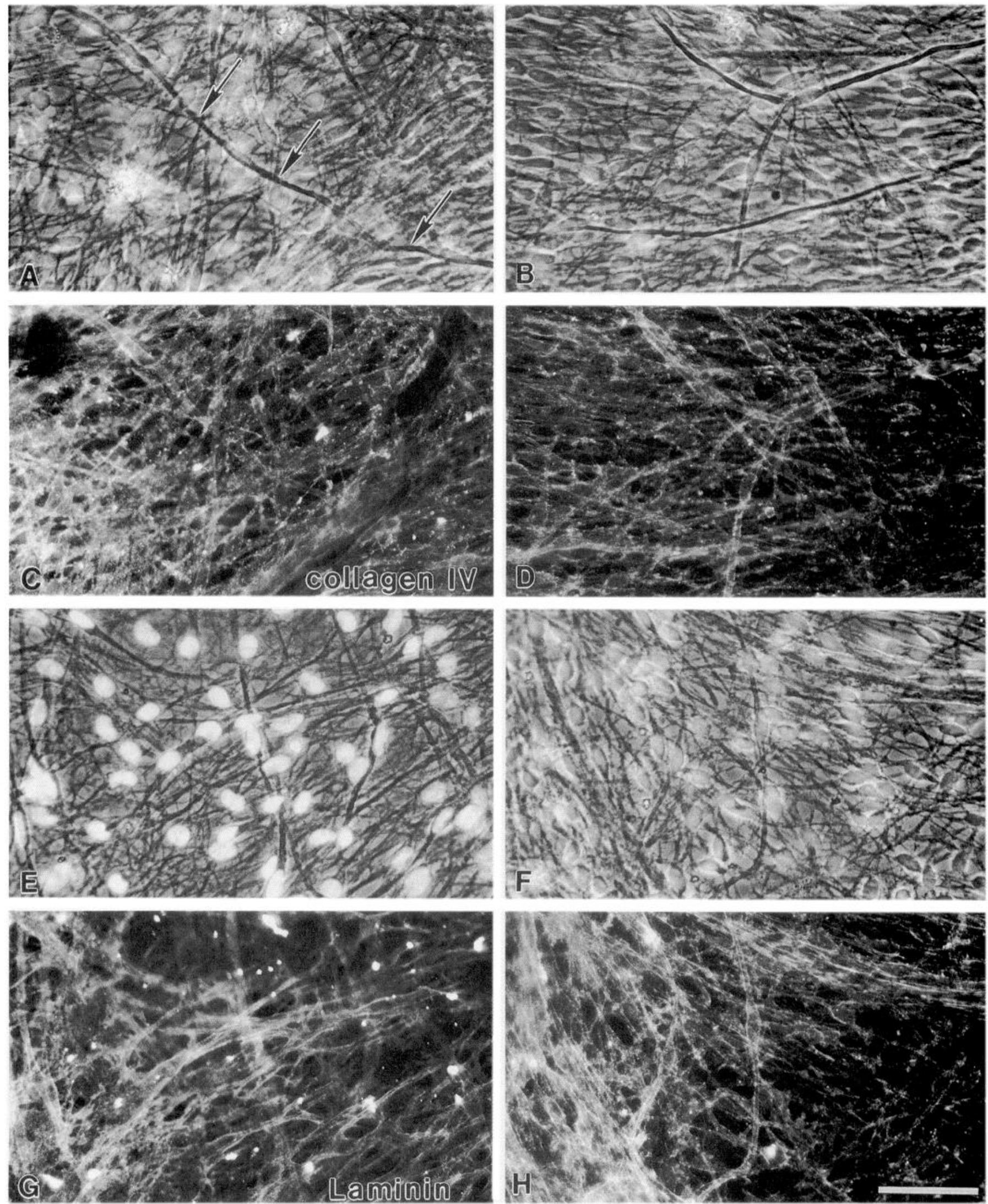

Figure 4. Comparison of the expression of collagen type IV and laminin in N-SC and N-SC-A cultures. Phase-contrast ( $A, E)$ and fluorescence $(C, G)$ micrographs show immunostaining with anti-collagen type IV $(C)$ and anti-laminin $(G)$ antibodies of an N-SC culture 2 weeks after switching in myelinating medium. By phase contrast, Schwann cells and myelinated axons (arrows) can be observed. In N-SC-A cultures [phase contrast ( $B$, $F)$, and fluorescence with anti-collagen type IV $(D)$ and anti-laminin $(H)$ antibodies], astrocytes underlying the Schwann cells and axons are not visible. By immunofluorescence, type IV collagen $(C, D)$ and laminin $(G, H)$ form a sheath surrounding the axons. The intensity of the type IV collagen and laminin staining in astrocyte-containing cultures is similar to that observed in controls. Scale bar, $100 \mu \mathrm{m}$. 
Table 4. Effect of astrocytes on basal lamina formation by Schwann cells

\begin{tabular}{llllcc} 
& $\begin{array}{l}\text { Number of } \\
\text { Schwann } \\
\text { cells }\end{array}$ & \multicolumn{3}{l}{ Schwann cells with basal lamina (\%) } \\
\cline { 3 - 6 } Condition & examined & Complete & Patchy & None & Total \\
\hline Control & 166 & 58.8 & 41.2 & 0 & 100 \\
Astrocytes & 140 & $17.5^{*}$ & 67.2 & 15.3 & 84.7 \\
\hline
\end{tabular}

Electron micrographs were examined to determine the amount of basal lamina deposited on the Schwann cell surface. A Schwann cell was considered to have basal lamina if a patchy or complete basal lamina was seen on the surface of the Schwann cell not in apposition to the axons. One-way ANOVA followed by Tukey posttest comparisons was used to test significance between pairs of means.

* Statistical significance $(p<0.05)$ between control and astrocyte groups.

not shown for the N-SC-ACM cultures. Thus, astrocytes and astrocyte-conditioned medium did not block the expression of two of the major components of Schwann cell basal lamina.

\section{Astrocytes decrease axonal ensheathment, the segregation of large axons into a 1:1 relationship, and basal lamina formation}

The effects of astrocytes on the axonal-Schwann cell relationship and basal lamina formation were studied by electron microscopy. Although the expression of type IV collagen and laminin by Schwann cells was not affected by astrocytes, ultrastructural analysis revealed slight differences in the amount of basal lamina deposition around the abaxonal surface of Schwann cells between control and astrocyte-containing cultures. A basal lamina was present around all axon-Schwann cell units in N-SC cultures (Fig. 5A, Table 4), being continuous in $58.8 \%$ of the units. In contrast, only $84.7 \%$ of the units in N-SC-A cultures displayed a basal lamina (Fig. $5 B, C$; Table 4 ). In $17.5 \%$ of the units examined, the basal lamina was complete, whereas in the remaining units the basal lamina was patchy and discontinuous. This slight decrease in basal lamina deposition in the presence of astrocytes is likely to reflect the fact that since less myelin is formed in N-SC-A than in N-SC cultures, basal lamina deposition which is proportional to myelination is decreased.

Differences in the state of axonal ensheathment between N-SC and N-SC-A cultures were striking after 2 weeks in M medium. In control cultures, Schwann cell processes had grown into the axon bundles. Bifurcating processes had subdivided the axonal fascicles, engulfing some of the axons (Fig. $5 \mathrm{~A}$ ). Most axons were ensheathed in groups; only $12.1 \%$ of them were singly ensheathed (Table 5). In N-SC-A cultures, the invasion of the axonal fascicles by Schwann cell processes was reduced and less advanced than in control cultures; Schwann cells extended a few short processes and occasionally a long process. These long processes were less bifurcated and engulfed larger groups of axons (Fig. 5B,C) in astrocyte-containing cultures than in control cultures. Axons with little interaction with Schwann cells were seen "trapped" between neighboring Schwann cells. Single axons surrounded by Schwann cell processes were occasionally observed but represented only $5.9 \%$ of the axons, a statistically significant reduction when compared to control cultures (Table 5). The percentage of axons engaged in 1:1 relationships was also significantly decreased in the presence of astrocytes (Table 5). Interestingly, astrocyte processes were rarely seen invading axon bundles. Although astrocytes reduced the extension of Schwann cell processes and thus interactions between axons and
Table 5. Effect of astrocytes on axonal ensheathment and segregation of large axons into 1:1 relationships by Schwann cells

\begin{tabular}{|c|c|c|c|c|c|}
\hline \multirow[b]{2}{*}{ Condition } & \multirow{2}{*}{$\begin{array}{l}\text { Number } \\
\text { of axons } \\
\text { examined }\end{array}$} & \multicolumn{3}{|c|}{ 1:1 relationships $(\%)$} & \multirow{2}{*}{$\begin{array}{l}\text { Ensheathed } \\
\text { axons } \\
\text { (\%) }\end{array}$} \\
\hline & & $\overline{\mathrm{MA}}$ & non- & Total & \\
\hline Control & 7,607 & 3.4 & 1.2 & $4.6^{\prime \prime}$ & 12.1 \\
\hline Astrocytes & 11,014 & $0.2^{*}$ & $0.5^{*}$ & $0.7^{*}$ & $2.9^{*}$ \\
\hline
\end{tabular}

Electron micrographs were examined for profiles indicating that single axona ensheathment or a 1:1 relationship had been established. An axon was considerer singly ensheathed when at least $50 \%$ of its surface was surrounded by Schwann cell cytoplasm that separated it from other axons ensheathed by the same Schwann cell. A 1:1 relationship was considered to be established if a Schwann cell was interacting with a single axon, completely ensheathing it, and if basal lamina was present around the axon-Schwann cell unit. One-way ANOVA followed by Tukey posttest comparisons was used to test significance between pairs of means.

a $1: 1$ relationships including nonmyelinated (non-MA) and myelinated (MA) axons are combined.

*Statistical significance $(p<0.0 .5)$ hetween control and astrocyte groups

Schwann cells were diminished, the astrocytes did not physically interfere with the contact between Schwann cells and axons (Fig. $5 B, C)$. Except in one culture where astrocytes separated axons and Schwann cells into nerve microfascicles, astrocytes always formed a carpet underneath the axons and their associated Schwann cells. This suggests that the effect of astrocytes on Schwann cell function is mediated by soluble factors.

\section{Astrocytes and astrocyte-conditioned medium do not induce neuronal morphological changes}

To assess if the effects of astrocytes or astrocyte-conditioned medium on myelination could be due to an indirect harmful influence on the neurons rather than on the Schwann cells themselves, the morphology of the neuronal somata of DRG neurons in neuron, $\mathrm{N}-\mathrm{A}$, and $\mathrm{N}-\mathrm{ACM}$ cultures was examined after maintenance in $\mathrm{M}$ medium for 4 weeks. In all groups of cultures, the cell bodies were round in shape, with a centered nucleus (data not shown). There was no significant difference in the size of the cell bodies among the groups $(70.4 \pm 0.7 \mu \mathrm{m}$ in neuronal cultures, $74.1 \pm 1.1 \mu \mathrm{m}$ in N-A cultures, and $64.4 \pm 1.0 \mu \mathrm{m}$ in $\mathrm{N}$-ACM cultures). Thus, neither astrocytes nor astrocyte-conditioned medium induced chromatolysis under the culture conditions tested.

\section{Astrocyte-conditioned medium does not show detectable $T G F-\beta$ and $T N F-\alpha$ activities}

Preliminary experiments (data not shown) to characterize further the astrocytc inhibitory factor(s) indicate that the factor(s) is heat stable; that is, its activity was retained after heating at $56^{\circ} \mathrm{C}$ or $100^{\circ} \mathrm{C}$ for $30 \mathrm{~min}$.

To test for TGF- $\beta$-like activity, serum-free astrocyte-conditioned medium was heated at $80^{\circ} \mathrm{C}$ for $8 \mathrm{~min}$, a treatment known to activate latent TGF- $\beta$. Heated astrocyte-conditioned medium did not inhibit Mv1Lu cell proliferation as would be expected if $\mathrm{TGF}-\beta$ were present, nor did healing further strengthen the inhibitory effect of the astrocyte factor(s) on Schwann cell proliferation on DRG neurites. Furthermore, the astrocyte inhibitory effects were not blocked by anti-TGF- $\beta 1$ antibody. TNF$\alpha$-like activity in astrocyte-conditioned medium was evaluated using the WEHI 164 cell survival assay, capable of detecting picogram quantities of TNF- $\alpha$. No WEHI 164 cell death was observed after treatment with medium generated by astrocytes. Thus, no detectable TGF- $\beta$ - or TNF- $\alpha$-like activity was found 

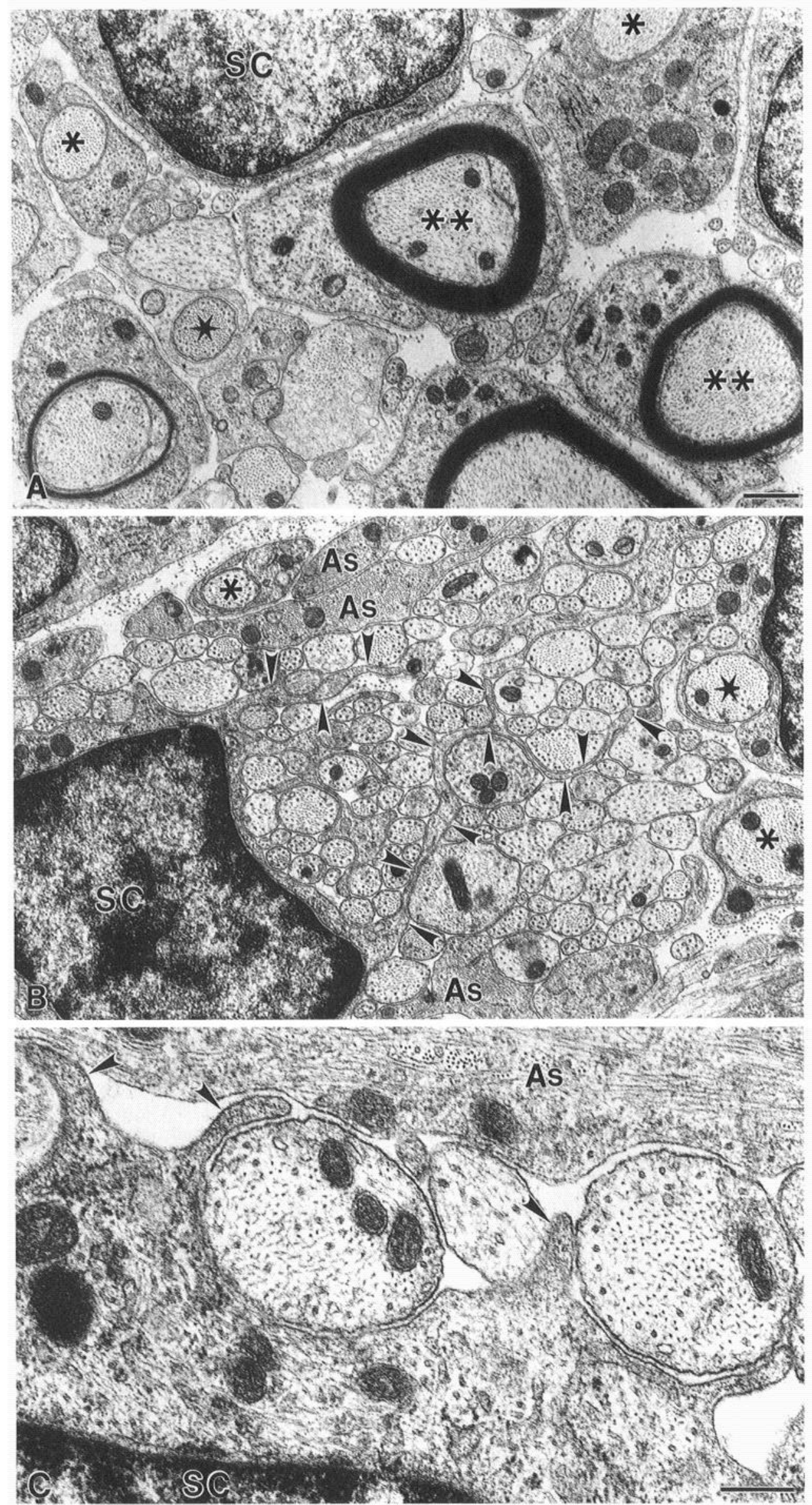

Figure 5. Electron micrographs of N-SC $(A)$ and N-SC-A $(B, C)$ cultures 2 weeks after switching to myelinating medium. In control cultures $(A)$ most axons are ensheathed (star) or segregated into myelinated 1:1 relationships (double asterisks). Myelin has formed and most Schwann cell $(S C)$-axon units are surrounded by a continuous basal lamina. In the presence of astrocytes $(B)$, axon-Schwann cell interactions are more limited (arrowheads); ensheathment (star) and 1:1 relationships (asterisk) are decreased. Astrocytes processes $(A s)$ are mostly localized on the side of the culture facing the substrate (upper side of $B$ ). At a higher magnification $(C)$, axons neighboring astrocyte processes $(A s)$ are only partially surrounded by Schwann cell processes (arrowheads). Scale bars: $A$ and $B, 5$ $\mu \mathrm{m} ; C, 0.5 \mu \mathrm{m}$. 
in the astrocyte-conditioned medium generated under our tissue culture conditions.

\section{Discussion}

The present study shows that cortical astrocytes inhibit Schwann cell proliferation and differentiation in vitro. Under the tissue culture conditions tested, Schwann cell division induced by DRG neurons and the formation of myelin sheaths were both inhibited by astrocytes. Furthermore, the expression of galactocerebroside, one of the earliest events in the myelination process (Wood et al., 1990), was inhibited by astrocytes. The segregation of large axons by Schwann cell processes into 1:1 relationships that precede myelination was also inhibited by astrocytes and basal lamina deposition was slightly decreased. These results indicate that astrocytes interfere with axon-Schwann cell interactions that are critical in the differentiation of Schwann cells into myelin-forming cells.

Soluble factors released by cortical astrocytes are partially responsible for the inhibition of Schwann cell proliferation and myelination. For instance, Schwann cell division was decreased, and $\mathrm{O} 1$ expression and myelination were inhibited by a factor(s) present in astrocyte-conditioned medium. Astrocytes release numerous factors that could affect Schwann cell function, including TGF- $\beta$ and TNF- $\alpha$ (Lieberman et al., 1989; Constam et al., 1992). Under our experimental conditions, astrocyte-conditioned medium did not contain demonstrable TGF- $\beta-$ or TNF$\alpha$-like activity.

The mechanisms by which astrocytes inhibit Schwann cell proliferation are unclear. Axonal surface molecules are known to stimulate Schwann cell proliferation (Wood and Bunge, 1975; Salzer et al., 1980). A factor(s) released by astrocytes could have interfered with the interaction between the axonal mitogen and its receptor on the Schwann cell surface. The possibility that Schwann cell division was blocked because of a lack of initial association or adhesion with neurites is unlikely since Schwann cells were seeded on the neuronal cultures $1 \mathrm{~d}$ prior to adding the astrocytes or their conditioned medium, allowing the establishment of Schwann cell-neuronal contact. An alternative possibility is that the astrocyte factor blocks some step in the intracellular signaling pathway that mediates the mitogenic response. Decrease in Schwann cell proliferation has also been noticed at demyelinated CNS sites as Schwann cells migrate into lesion sites (Blakemore, 1975; Raine et al., 1978; Gilmore et al., 1982; Sims and Gilmore, 1983, 1989; Harrison, 1985; Dusart et al., 1989). Sims and Gilmore (1989) attributed this decrease in Schwann cell proliferation to an association with large-caliber demyelinated axons that caused the invading Schwann cells to stop dividing and prematurely differentiate. Thesc studics did not consider the possibility that other CNS cellular and/or humoral elements could have affected Schwann cell proliferation. Our data support the latter hypothesis and indicate that the decrease in Schwann cell proliferation seen in in vivo studies could also be due to proliferation inhibitory factors released by astrocytes present near or within CNS lesions.

The mechanisms by which cortical astrocytes, or soluble factors released by astrocytes, interfere with myelination are also unclear. The insertion of Schwann cell processes into axonal fascicles, the engulfment of axons, and segregation of axons into $1: 1$ relationships with Schwann cell processes are decreased in the presence of astrocytes. Since these steps must occur before myelination can begin, our observations suggest that Schwann cell differentiation is inhibited by astrocytes at a stage prior to the initiation of myelination. This hypothesis is supported by the observation that in the presence of astrocytes the expression of $\mathrm{O} 1$, but not that of $\mathrm{O} 4$, was inhibited. Furthermore, the expression of the ECM molecules laminin and collagen type IV by Schwann cells was not influenced by astrocytes. Basal lamina formation, an event linked to axonal engulfment, segregation, and a prerequisite in the formation of myelin (Eldridge et al., 1987), was only slightly decreased. We do not believe that the decrease in basal lamina formation in the presence of astrocytes explains the inhibition of myelination. Adding laminin to myelinating medium (Eldridge et al., 1989) increased both axonal ensheathment and basal lamina deposition but did not improve myelination in the presence of astrocytes (V. Guenard and P. M. Wood, unpublished observation). Astrocytes thus seem to interfere with the normal course of axon-Schwann cell interactions that lead to full Schwann cell maturation.

This pattern of inhibition of Schwann cell differentiation resembles that observed in the presence of antibodies to the neural cell adhesion molecule (CAM) L1 (Wood et al., 1990). Recent observations suggest that CAM-mediated events may involve the induction of gene expression in the responsive cell (Schuch et al., 1989). An explanation for the inhibition of Schwann cell differentiation by cortical astrocytes could be that they release factors that block CAM-mediated shape changes necessary for Schwann cell process extension. Alternatively, the astrocyte factor could block intracellular pathways of gene induction triggered by Schwann cell receptor binding to axonal or basal lamina ligands. For example, the expression of the gene coding for myelin-associated glycoprotein, which is believed to be involved in the segregation of axons (Owens et al., 1990), could be blocked by the astrocyte factor. Astrocytes of similar origin have been demonstrated to release a soluble factor(s) with similar effects on oligodendrocytes associated with DRG neurites in culture, decreasing both their proliferation and ability to myelinate (Rosen et al., 1989). Interestingly, anti-Ll antibody also blocks oligodendrocyte myelination of sensory axons in culture (J. Archelos and P. M. Wood, unpublished observations). The fact that oligodendrocyte myelination is blocked suggests that the astrocyte factor inhibits interactions specifically involved in differentiation toward myelination.

The fact that the observed effects of cortical astrocytes on Schwann cell proliferation or myelination are on specific Schwann cell functions and are not due to generalized cytotoxicity is demonstrated by several of our observations. First, the astrocyte inhibitory factor(s) did not affect the expression of $\mathrm{O} 4$, one of the earliest stages of Schwann cell differentiation, nor did it influence the expression of laminin and collagen type IV, two of the major components of basal lamina involved in myelinating processes. In addition, preexisting myelin was only slightly degraded, if at all, by astrocytes and astrocyte-conditioned medium. The findings that the observed effects represent a cellspecific property of astrocytes was shown by comparing the influence of fibroblasts and their released factor(s) using similar tissue culture conditions. Fibroblasts were chosen for this comparison because they exhibit a pattern of growth much like that of astrocytes in culture. Both fibroblasts and fibroblast-conditioned medium failed to inhibit Schwann cell proliferation. Furthermore, indirect harmful effects of astrocytes and their released factor(s) on neuronal health or physical blockage of Schwann cell-axonal interactions by astrocyte processes cannot be responsible for the astrocyte effects. No evidence of chromatolytic or axonal morphological changes was observed in our 
cultures, and at the ultrastructural level, all cultures but one showed astrocytes forming a carpet underneath the neurons and Schwann cells; astrocyte processes did not appear to intermingle directly with Schwann cell processes and neurites. Thus, the astrocyte effects are not due to physical interference with Schwann cell process extension or to physical blocking by astrocyte processes of access of Schwann cell process to axonal ligands.

Our finding that astrocytes inhibit Schwann cell myelination in vitro correlates with the reported evidence that reactive (i.e., GFAP-positive) astrocytes limit Schwann cell remyelination in vivo in the demyelinated or damaged CNS (Ghatak et al., 1973; Itoyama et al., 1983, 1985). Astrocytes also seem to limit host Schwann cell penetration in the cord (Blakemore, 1975; Sims and Gilmore, 1983; Harrison, 1985). In their transplantation studies using CNS-derived glial cell cultures, Blakemore and Crang (1989) demonstrated that the extent of remyelination by endogenous Schwann cells depends on the presence of type 1 astrocytes in the injected cell suspension. Schwann cell remyelination exceeded on oligodendrocyte remyelination only when cultures deficient in type 1 astrocytes were transplanted. BaronVan Evercooren et al. (1992) reported that Schwann cells transplanted into the brain of newborn shiverer mice are excluded by astrocytes in areas containing endogenous oligodendrocytes; astrocytes limited Schwann cell migration and prevented the formation of myelin by the grafted Schwann cells. Sims and Gilmore (1983) and Blakemore et al. (1986) also noted that more CNS fibers are myelinated by Schwann cells in areas containing few astrocytes. Recent studies completed in our laboratory have shown that cortical astrocytes transplanted together with purified populations of Schwann cells in semipermeable guidance channels (Guénard et al., 1992) decrease the ability of Schwann cells both to enhance peripheral nerve regeneration and form myelin (Guénard et al., 1994). These results further strengthen the interpretation that the results of the present study may be extrapolated to the in vivo situation. The possibility that Schwann cells decrease the astrocytic reaction observed by others also exists but has not yet been elucidated.

Even though these results apply to astrocytes obtained from cortical tissue, there is no current evidence that astrocytes isolated from other areas of the brain or the spinal cord would behave differently in this system.

We conclude that purified cortical astrocytes inhibit both the neuron-dependent proliferation of Schwann cells and myelination of axons by Schwann cells in vitro, some of these effects being mediated by a soluble factor(s) secreted by astrocytes. These findings should be considered prior to designing strategies based on Schwann cell transplantation to repair the injured or demyelinated CNS, a method with future clinical application (Bunge, 1975). Decreasing the extent of the astrocytic reaction and/or inhibiting the activity of astrocyte inhibitory factor(s) may improve the effectiveness of the Schwann cell transplants. Characterization of the astrocyte inhibitory factor(s) is thus important and is currently underway. It is our hope that these studies will lead to an improved understanding of some of the cellular responses observed following demyelination.

\section{References}

Acheson A, Baker PA, Alderson RF, Miller FD, Murphy RA (1991) Detection of brain-derived neurotrophic factor-like activity in fibroblasts and Schwann cells: inhibition by antibodies to NGF. Neuron 7:265-275.

Bandtlow CE, Heumann R, Schwab ME, Thoenen H (1987) Cellular localization of nerve growth factor synthesis by in situ hybridization. EMBO J 6:891-899.

Bansal R, Warrington AE, Gard AL, Ranscht B, Pfeiffer SE (1989) Multiple and novel specificities of monoclonal antibodies $\mathrm{O} 1, \mathrm{O} 4$ and R.mAb in the analysis of oligodendrocyte development. J Neurosci Res 24:548-557.

Barnard JA, Lyons RM, Moses HL (1990) The cell biology of transforming growth factor $\beta$. Biochem Biophys Acta 1032:79-87.

Baron-Van Evercooren A, Clerin-Duhamel E, Lapie P, Gansmuller A, Lachapelle F, Gumpel M (1992) The fate of Schwann cells transplanted in the brain during development. Dev Neurosci 14:73-84.

Bignami A, Dahl D (1976) The astroglial response to stabbing. Immunofluorescence studies with antibodies to astrocyte-specific protein (GFA) in mammalian and submammalian vertebrates. Neuropathol Appl Neurobiol 2:99-110.

Bignami A, Eng LF, Dahl D, Uyeda CT (1972) Localization of the glial fibrillary acidic protein in astrocytes by immunofluorescence. Brain Res 43:429-435.

Blakemore WF (1975) Remyelination by Schwann cells of axons demyelinated by intraspinal injection of 6-aminonicotinamide in the rat. J Neurocytol 4:754-757.

Blakemore WF (1977) Remyelination of CNS axons by Schwann cells transplanted from the sciatic nerve. Nature 266:68-69.

Blakemore WF, Crang AJ (1989) The relationship between type-1 astrocytes, Schwann cells and oligodendrocytes following transplantation of glial cell cultures into demyelinating lesions in the adult rat spinal cord. J Neurocytol 18:519-528.

Blakemore WF, Crang AJ, Curtis R (1986) The interaction of Schwann cells with CNS axons in regions containing normal astrocytes. Acta Neuropathol (Berl) 71:295-300.

Brockes JP, Fields KL, Raff MC (1979) Studies on cultured rat Schwann cells. I. Establishment of purified populations from cultures of peripheral nerves. Brain Res 165:105-118.

Bunge MB, Bunge RP, Carey DJ, Cornbrooks CJ, Eldridge CF, Williams AK, Wood PM (1983) Axonal and non-axonal influences on Schwann cell development. In: Developing and regenerating vertebrate nervous systems (Coates PW, Markwald RR, Kenny AD, eds), pp 71-105. New York: Liss.

Bunge RP (1975) Changes uses of nerve tissue culture 1950-1975. In: The nervous system, $\mathrm{Vol} 1$, The basic neurosciences (Tower BD, ed), pp 31-42. New York: Raven.

Bunge RP, Bunge MB, Eldridge CF (1986) Linkage between axonal ensheathment and basal lamina production by Schwann cells. Annu Rev Neurosci 9:305-328.

Bunge RP, Bunge MB, Bates M (1989) Movements of the Schwann cell nucleus implicate progression of the inner (axon-related) Schwann cell process during myelination. J Cell Biol 109:273-284.

Campbell G, Lieberman AR, Anderson PN, Turmaine M (1992) Regeneration of adult rat CNS axons into peripheral nerve autografts: ultrastructural studies on the early stages of axonal sprouting and regenerative axonal growth. J Neurocytol 21:755-787.

Carey DJ, Eldridge CF, Cornbrooks CJ, Timpl R, Bunge RP (1983) Biosynthesis of type IV collagen by cultured rat Schwann cells. J Cell Biol 97:473-479.

Cockram CS (1990) Growth factors, astrocytes and astrocytomas. Semin Dev Biol 1:421-435.

Constam DB, Philipp J, Malipiero UV, Dijke PT, Schachner M, Fontana A (1992) Differential expression of transforming growth factor- $\beta 1$, $-\beta 2$ and $-\beta 3$ by glioblastoma cells, astrocytes, and microglia. J Immunol 148:1404-1410.

Danielpour D, Dart LL, Flanders KC, Roberts AB, Sporn MB (1989) Immunodetection and quantitation of the two forms of transforming growth factor-Beta (TGF- $\beta 1$ and TGF- $\beta 2$ ) secreted by cells in culture. J Cell Physiol 138:79-86.

David S, Aguayo AJ (1981) Axonal elongation into peripheral nervous system "bridges" after central nervous system injury in adult rats. Science 214:931-933.

Duncan ID, Hammang JP, Jackson KF, Wood PM, Bunge RP, Langford L (1988) Transplantation of oligodendrocytes and Schwann cells into the spinal cord of the myelin-deficient rat. J Neurocytol 17:351360.

Dusart I, Isacson O, Nothias F, Gumpel M, Peschanski M (1989) Presence of Schwann cells in neurodegenerative lesions of the central nervous system. Neurosci Lett 105:246-250.

Eldridge CF, Bunge MB, Bunge RP, Wood PM (1987) Differentiation 
of axon-related Schwann cells in vitro: I. Ascorbic acid regulates basal lamina assembly and myelin formation. J Cell Biol 105:1023-1034.

Eldridge CF, Bunge MB, Bunge RP (1989) Differentiation of axonrelated Schwann cells in vitro: II. Control of myelin formation by basal lamina. J Neurosci 9:625-638.

Fawcett JW, Keynes RJ (1990) Peripheral nerve regeneration. Annu Rev Neurosci 13:43-60.

Ghatak NR, Hirano A, Doron Y, Zimmerman HM (1973) Remyelination in multiple sclerosis with peripheral type myelin. Arch Neurol 29:262-267.

Gilmore SA, Sims TJ, Heard JK (1982) Autoradiographic and ultrastructural studies of areas of spinal cord occupied by Schwann cells and Schwann cell myelin. Brain Res 239:365-375.

Guénard V, Kleitman N, Morrissey TK, Bunge RP, Aebischer P (1992) Syngeneic Schwann cells derived from adult nerves seeded in semipermeable guidance channels enhance peripheral nerve regeneration. J Neurosci 12:3310-3320.

Guénard V, Xu XM, Bunge MB (1993) The use of Schwann cell transplantation to foster central nervous system repair. Semin Neurosci 5: in press.

Guénard V, Aebischer P, Bunge RP (1994) The astrocytc inhibition of peripheral nerve regeneration is reversed by Schwann cells. Exp Neurol, in press.

Harrison BM (1980) Remyelination by cells introduced into a stable demyelinating lesion in the central nervous system. J Neurol Sci 46: 63-81.

Harrison B (1985) Schwann cell and oligodendrocyte remyelination in lysolecithin-induced lesions in irradiated rat spinal cord. J Neurol Sci 67:143-159.

Hatten ME, Liem RKH, Shelanski ML, Mason CA (1991) Astroglia in CNS injury. Glia 4:233-243.

Itoyama Y, Webster HF, Richardson EP, Trapp BD (1983) Schwann cell remyelination of demyelinated axons in spinal cord multiple sclerosis lesions. Ann Neurol 14:339-346.

Itoyama Y, Ohnishi A, Tatcishi J, Kuroiwa Y, Wcbstcr HF (1985) Spinal cord multiple sclerosis lesions in Japanese patients: Schwann cell remyelination occurs in areas that lack glial fibrillary acidic protein (GFAP). Acta Neuropathol (Berl) 65:217-223.

Kleitman N, Wood PM, Bunge RP (1991) Tissue culture methods for the study of myelination. In: Culturing nerve cells (Banker G, Goslin $\mathrm{K}$, eds), pp 337-377. Cambridge, MA: MIT Press.

Kromer LF, Cornbrooks CJ (1985) Transplants of Schwann cell cultures promote axonal regeneration in the adult mammalian brain. Proc Natl Acad Sci USA 82:6330-6334.

Kumar S, Huber J, Pena LA, Perez-Polo JR, Werrbach-Perez K, de Vellis J (1990) Characterization of functional nerve growth factorreceptors in a CNS glial cell line: monoclonal antibody $217 \mathrm{c}$ recognizes the nerve growth factor receptor on C6 glioma cells. J Neurosci Res 27:408-417.

Lieberman AP, Pitha PM, Shin HS, Shin ML (1989) Production of tumor necrosis factor and other cytokines by astrocytes stimulated with polysaccharide or a neurotropic virus. Proc Natl Acad Sci USA 86:6348-6352.

McCarthy K, deVellis J (1980) Preparation of separate astroglial and oligodendroglial cell cultures from rat cerebral tissue. J Cell Biol 85 : 890-902.

Muir D, Gennrich C, Varon S, Manthorpe M (1989) Rat sciatic nerve Schwann cell microcultures. Responses to mitogens and production of trophic and neurite-promoting factors. Neurochem Res 14:10031012 .

Nieto-Sampedro M, Manthorpe M, Barbin G, Varon S, Cotman CW (1983) Injury-induced neuronotrophic activity in adult rat brain: correlation with delayed implants in the wound cavity. J Neurosci 3:2219-2229.

Owens GC, Boyd CJ, Bunge RP, Salzer JL (1990) Expression of recombinant myelin-associated glycoprotein in primary Schwann cells promotes the initial investment of axons by myelinating Schwann cells. J Cell Biol 111:1171-1182.

Paino C, Bunge MB (1991) Induction of axon growth into Schwann cell implants grafted into lesioned adult rat spinal cord. Exp Neurol 114:254-257.

Politis MJ, Spencer PS (1986) Regeneration of rat optic axons into peripheral nerve grafts. Exp Neurol 91:52-59.

Porter S, Clark MB, Glaser L, Bunge RP (1986) Schwann cells stimulated to proliferate in the presence of neurons retain full functional capability. J Neurosci 6:3070-3078.
Raff MC, Fields KL, Hakomori SI, Mirsky R, Pruss RM, Winter I (1979) Cell type-specific markers for distinguishing and studying neurons and the major classes of glial cells in culture. Brain Res 174 283-308.

Raff MC, Abney ER, Cohen J, Lindsay R, Noble M (1983) Two types of astrocytes in cultures of developing white matter: differences in morphology, surface gangliosides, and growth characteristics. J Neurosci 3:1289-1300.

Raine CS, Traugott U, Stone SH (1978) Glial bridges and Schwann cell migration during chronic demyelination in the CNS. J Neurocytol 7:541-553.

Reier PJ, Houle JD (1988) The glial scar: its bearing on axonal elongation and transplantation approaches to CNS repair. In: Functional recovery in neurological disease, Vol 47 (Waxman SG, ed), pp 87 138. New York: Raven.

Rende M, Muir D, Ruoshlati E, Hagg T, Varon S, Manthorpe M (1992) Immunolocalization of ciliary neurotrophic factor in the adult rat sciatic nerve. Glia 5:25-32.

Richardson PM, McGuinness UM, Aguayo AJ (1982) Peripheral nerve autografts to the rat spinal cord: studies with axonal tracing methods. Brain Res 237:147-162.

Robbins DS, Shirazi Y, Drysdale B, Lieberman A, Shin HS, Shin ML (1987) Production of cytotoxic factor for oligodendrocytes by stimulated astrocytes. J Immunol 139:2593-2597.

Robinson AP, White TM, Mason DW (1986) Macrophage heterogeneity in the rat as delineated by two monoclonal antibodies MRC $\mathrm{OX}-41$ and $\mathrm{OX}-42$, the latter recognizing the complement receptor type 3. Immunology 57:239-247.

Rosen CL, Bunge RP, Ard MD, Wood PM (1989) Type 1 astrocytes inhibit myelination by adult rat oligodendrocytes in vitro. J Neurosci 9:3371-3379.

Salzer JL, Bunge RP, Glaser L (1980) Studies of Schwann cell proliferation: III. Evidence for the surface localization of the neurite mitogen. J Cell Biol 84:767-778.

Schuch U, Lohse MJ, Schachner M (1989) Ncural cell adhesion molecules influence second messenger systems. Neuron 3:13-20.

Selmaj K, Raine CS, Farooq M, Norton WT, Brosnan CF (1991) Cytokine cytotoxicity against oligodendrocytes: apoptosis induced by lymphotoxin. J Immunol 147:1522-1529.

Sims TJ, Gilmore SA (1983) Interactions between intraspinal Schwann cells and the cellular constituents normally occurring in the spinal cord: an ultrastructural study in the irradiated rat. Brain Res 276:1730.

Sims TJ, Gilmore SA (1989) Interactions between Schwann cells and CNS axons following a delay in normal formation of central myelin. Exp Brain Res 75:513-522.

Smith GV, Stevenson JA (1988) Peripheral nerve grafts lacking viable Schwann cells fail to support central nervous system axonal regeneration. Exp Brain Res 69:299-306.

Sommer I, Schachner M (1981) Monoclonal antibodies (O1 to O4) to oligodendrocyte cell surfaces: an immunological study in the central nervous system. Dev Biol 83:311-327.

Vanderslice WE, Collins JL (1991) Differences in the tumor necrosis factor- $\alpha$-mediated lysis by fixed natural cytotoxic cells and fixed cytotoxic macrophages. J Immunol 146:156-161.

Weinberg EL, Raine CS (1980) Reinnervation of peripheral nerve segments implanted into the rat central nervous system. Brain Res 198:1-11.

Wood PM, Bunge RP (1975) Evidence that sensory axons are mitogenic for Schwann cells. Nature 256:662-664

Wood PM, Williams AK (1984) Oligodendrocyte proliferation and CNS myelination in cultures containing dissociated embryonic neuroglia and dorsal root ganglion neurons. Dev Brain Res 12:225-241.

Wood PM, Schachner M, Bunge RP (1990) Inhibition of Schwann cell myelination in vitro by antibody to the $\mathrm{Ll}$ adhesion molecule. J Neurosci 10:3635-3645.

Wrathall JR, Rigamonti DD, Bradford MR, Kao CC (1982) Reconstruction of the contused cat spinal cord by the delayed nerve graft technique and cultured peripheral non-neuronal cells. Acta Neuropathol (Berl) 57:59-69.

Xu XM, Guénard V, Chen A, Kleitman N, Bunge MB (1993) Rostral and caudal axonal regeneration into Schwann cell-seeded guidance channels grafted into a gap in adult rat spinal cord. Soc Neurosci Abstr 19:681. 